\title{
A Manager-Customer Empirical Investigation Of The Subjective Performance Of Proactive Market-Oriented Consumer Goods Companies: Testing A Double-Mediation Model
}

Laurent Tournois, Laboratoire d'Economie et de Management de Nantes-Atlantique(LEMNA), France

\begin{abstract}
This study investigates the mediating role of perceived branded product leadership and perceived customer value in the relationship between of proactive market orientation on performance (corporate reputation) in a consumer goods setting. A manager-customer approach is adopted: data was collected from 146 managers from 55 companies, and 425 customers that purchased their branded products. Results show that companies that practice a high level of proactive market orientation are perceived as leaders, which leads to higher levels of customer perceived value of their branded products and enhanced reputation. This research adds to the existing literature in considering customers' perceptual assessments.
\end{abstract}

Keywords: Proactive Market Orientation; Branded Product Leadership; Customer Value; Reputation; Consumer Goods Companies; Double Mediation

\section{INTRODUCTION}

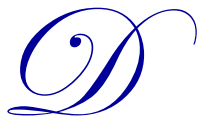

uring market decline, companies may (re)place the customer at the core of their strategy as part of a proactive marketing approach that characterizes their strategic response to hostile environments (e.g. Srinivasan Rangaswamy, \& Lilien, 2005; Samli, 2006). As such, it appears to be the only way to outperform competitors who tend to imitate any successful initiative because "the risks of copying are offset by the difficulty of coming up with brilliant new alternatives" (Aaker, 2012, p.1979). This view considers that even a tough business context contains dis guised or latent opportunities that can be exploited to develop new products that serve as means of differentiation to aid a firm in attaining product category leadership (Gehlhar, Regmi, Stefanou, \& Zoumas, 2009). Such perspective echoes recent advances in the market orientation literature and particularly on its conceptual development on proactive market oriented behaviour that focuses on revealing customers' unexpressed needs (Narver, Slater, \& MacLachlan, 2004), a prerequisite in creating an advantage for the company that translates into superior perceived customer value and ultimately an enhanced performance.

While market orientation is a long established concept in marketing, it still offers substantialopportunities to add to our knowledge in the field. Indeed, the market orientation-perceived value-performance relationships literature relates to disputable conceptual perspectives on identifying the proper mediators and shows deficiency when it comes to considering customer-related outcomes. Below, we point out a number of areas that drive the aim of this paper to deliver a contribution.

First, questions of judgment and perception in evaluating the effectiveness of market orientation have been raised as important is sues (see Noble, Sinha, \& Kumar, 2002). Although market orientation's aim at creating superior value to customers has been argued since the earlier works of Kohli and Jaworski (1990), Narver and Slater (1990), and 
Deshpandé, Farley, and Webster (1993), it is not until recently that the link has been investigated by Blocker, Flint, Myers, and Slater (2011). Theses authors showed that proactive customer orientation creates superior value in a business-to-business setting. It reflects a 20 years old customer-centric view of market orientation (see Deshpandé, Farley, \& Webster, 1993) stressing that evaluations of the level of market orientation should come from customers rather than the company. Thus, in response to the deficiency of managers' self-as ses sments of performance indicators, they developed a "customer-defined market orientation" that takes into account customers' viewpoints in evaluating the value created by the company. This research stream marked by buyer-seller relationships (e.g. Langerak, 2001; Siguaw, Simpson, \& Baker, 1998), embodies a wider perspective of customer participation in evaluating the effectiveness of market orientation. However, in a business-to-consumercontext, it is not realistic to examine market orientation from a customer pers pective because they have little or no knowledge about a certain company's managers' behaviours and practices. Indeed, customers may assess its market orientation only to the extent the firm listens to their needs (Grisaffe \& Kumar, 1998). Moreover, unlike in services or buyer-supplier relationships, in consumer goods' settings customer interaction (i.e. the data obtained from) does not appear as such but indirectly through product returns, customer feedbacks and complaints, warranty claims, close ties with lead-users (e.g. von Hippel, 1986; see also, Narver, Slater, \& MacLachlan, 2004), and market insights that companies use to reveal latent needs and thus improve existing products or develop innovative ones. In line with the preceding arguments and considering the lack of theoretical and empirical developments, it is worth assuming that the nature and characteristics of a company's offer(s) are an indirect function of its level of market orientation, i.e. customers' perceptions, opposed to those of managers, about the extent to which a company is proactively market oriented are the right measures of its success in the market place.

Second, brands have rarely been considered in the market orientation literature although consumers "do not purchase a firm's goods and services simply because the firm has a particulartype of culture" (Hult, Ketchen, \& Slater, 2005, p. 1174). Because brands serve the role of identifying and differentiating a firms' offerings from those of its competitors (Tuominen, 1999) and that building strong brands ensures higher earnings (Aaker, 1996), it provides support to include brand related variables when studying the market orientation-performance relationship in a consumer goods setting. Furthermore, over the past 15 years manager's role has evolved towards the brand leaders hip paradigm meaning that it has become strategic and visionary rather than tactical and re active (Joachimsthaler, 2001). Here, the argument is that because strategic vision and corporate culture are intertwined (Aaker \& Joachimsthaler, 2000), it should be reflected in the way consumer goods companies proactively manage their branded products to differentiate them from competition.

Third, within its parent research domain, direct or indirect contribution of market orientation to perceived customer value and/or firm performance suffers from what was called a "black box" issue (e.g. Ben Brik, Rettab, \& Mellahi, 2010; Ellinger, Ketchen, Hult, Elmadag, \& Richey, 2008). An extensive debate regarding the market orientationperformance link still prevails in the literature. On the one hand, prior empirical studies revealed inconsistencies regarding the amplitude and direction of the relationship between market orientation and organizational performance (Kirca, Jayachandran, \& Bearden, 2005). These results limit the generalizability of the findings across settings. On the other hand, there is a trend of studies on mediating effects (e.g. Camarero \& Garrido, 2008; Carbonell \& Rodríguez Escudero, 2010; Noble, Sinha, \& Kumar, 2002; Roshayani, Siti Mariam, \& Rohana, 2012; Voola, Casimir, Carlson, \& Agnihotri, 2012) suggesting that the link is not direct. As such, there appears to be an argument that firms in consumer product markets with strong market oriented behaviours do not expect a direct performance improvement but rather "give voice to their customers" using various customer-related metrics when evaluating the effectiveness of their orientation toward the markets they serve. Interestingly, marketing literature reveals very little empirical evidence when it comes to examine the causal sequence that involves an organizational antecedent such as market orie ntation, multiple mediators, and various objective and/orsubjective performance indicators in the context of consumer goods companies. Therefore, market orientation's ability to enhance perceived customer value of branded products and generate superior performance based on integrating the customers' perceptions into the process has yet to be addressed in a business-to-consumer setting.

Finally, within the market orientation literature, there are difficulties and controversies in deciding which performance measures to use (Uncles, 2011). In an attempt to explain company performance, scholars have stressed the role of nonfinancial information among the factors that may contribute to it (Zeghal \& Maaloul, 2010). To encompass the 
spectrum of financial and non-financial concerns in evaluating performance, we consider reputation as a multidimensional customer related outcome. It should be noted that reputation is a subjective, customer-driven measure that complements more than replaces traditional internal measures (e.g., Walsh \& Beatty, 2007), and emphasizes comparisons among companies (Deephouse \& Carter, 2005). In this regard, we aim to adding to the contention that when a company is well known, observers (such as its customers) have a strong sense of what is central and distinctive about its attributes, particularly relative to other firms (Whetten \& Mackey 2002). Accordingly, our argument is that leading consumer goods companies strive through their proactive market oriented behaviour and their branded products, to be known in the market place which refers to one of the dominant conceptualization of reputation (see Lange, Lee, \& Dai, 2011). Finally, in considering - proactive market orientation as - an organizational antecedent to reputation, this study intends to provide empirical evidence to the very rare studies conducted on this type of relationship (e.g. Heugens, van Riel, \& van den Bosch, 2004).

The remainder of this paper is organized as follows. Foremost, this research presents the multisource (i.e. managercustomer) perspective that is adopted in a consumer goods setting. Then, the theoretical foundations that support several hypothesized relationships between proactive market orientation and various customer-related outcomes are developed. Finally, hypotheses are examined using the method suggested by Preacher and Hayes (2008a) in the case of a three-path model (two mediators in series).

\section{A MANAGER-CUS TOMER PERSPECTIVE ON THE PROACTIVE MARKET ORIENTATION-PERFORMANCE RELATIONS HIP}

Research has recently begun examining the impact of proactive market orientation on variables such new product performance (Chou \& Yang, 2011), new product development program performance (Srivastava, Yoo, Frankwick, \& Voss, 2013), innovation performance (Bodlaj, 2010), and firm performance (Voola \& O'Cass, 2010). Moreover, O'Cass and Ngo (2007) examined the joint effect of market orientation and innovative culture on brand performance. The (performance) outcomes used in these studies are evaluated through managers' self-as sessments, i.e. self-reported measures. Moreover, Blocker, Flint, Myers, and Slater's (2011) study showed that proactive customer orientation creates superior value in a business -to-business setting. In contrast with these authors, we do not develop a customerdefined view of proactive customer orientation (i.e. customer value), which better fits buyer-supplier relationships. Rather, we examine individual (vs. business) customers and branded consumer (versus industrial) products, and thus take into account the customer's perspective. The underlying reasoning is that in a business-to-consumersetting and particularly for consumer goods companies, it is their customers who determine if their branded products differentiate from the competition and possess superior perceived value. From the results of recent works (e.g. Zhou, Brown, \& Dev, 2009), we therefore adopt and extend the multisource pers pective (see Atwater, Brett, \& Charles, 2007; Bracken, Timmreck, Fleenor, \& Summers, 2001; Tornow, 1993) to empirically as sess these as sociations, i.e. both the company and its customers evaluating different concepts instead of self-reported measures of identical concepts. From a methodological standpoint, this approach has been popularized in human resource management studies (for a review, see Smither, London, \& Reilly, 2005) as an important mechanism for employees and managers' performance improvements. This view converges with that of this study to the extent that marketing scholars state that customers' evaluations avoid common method biases associated to managers' self-assessments of both market orientation and performance of their own business unit(s)(Rong \& Wilkinson, 2011).

\section{CONCEPTUAL FRAMEWORK AND HYPOTHES ES DEVELOPMENT}

\section{Theoretical Perspective}

The conceptual framework and hypotheses are derived from the following statement: dominant approaches to the market orientation concept have the main common denominator to be considered as achieving a competitive advantage [in terms of differentiation] that in return generates a superior perceived customer value (which varies from one company to another), and ultimately drives higher performance. In es sence, this sequence rais es not only the question of whether or not market orientation generates a competitive advantage but also the nature of the latter from both the perspective of the consumer goods companies and their customers. 
From the perspective of the company, within the market orientation literature, scholars have responded differently with regard to market conditions although not mentioned explicitly. Since the works of Narver and Slater (1990) and Kohli and Jaworski (1990), the dominant research stream has addressed the issue of developing a competitive advantage, perceived customervalue and various performance outcomes mainly through the lens of responsive market orientation i.e. satis fying customers' expressed needs. Nevertheless, from the perspective of the firm, simply satisfying customers stated needs prevents market oriented firms from anticipating threats from potential entrants, thus hampering a market orientation's capability to provide a competitive advantage (Kumar, Jones, Venkates an, \& Leone, 2011). Indeed, customers' expressed needs are effortlessly identifiable by all competitors making product benefits easier to imitate, and finally forcing the company to engage in aggressive price competition in the attempt to create higher value for the customers (Narver, Slater, \& MacLachlan, 2004).

From a customer's perspective, such a situation may result from a lack of perceived difference in value between two branded products, i.e. their respective benefits-to-sacrifice trade-offs are similar. In other words, products are perceived as being interchangeable which is a major signal of commoditization in a given product market (Reimann, Schilke, \& Thomas, 2010). In order to create the basis for meaningful differentiation and therefore get out of a price war (e.g. Porter, 1980), it has been argued that leading firms (e.g., Bourgeois, 1984) proactively influence their environments and drive market changes to maintain a leading position. In terms of conceptua lization, such a behaviour that goes beyond simply responding to customers' expressed needs to revealing their latent needs is named proactive market orientation (Narver, Slater, \& MacLachlan, 2004). The underlying rationale being for a company to differentiate its branded products on attributes that are not comparable to competition, and thus to modify the structure of a given market and consumers' decision process (Jaworski, Kohli, \& Sahay, 2000). Accordingly, consumer goods companies which branded products are dominant in their product category are supposed to hold a unique position in the marketplace, and presumably in the minds of their customers. This view is supported by a substantial body of literature that has identified the decision rules employed by consumers to assess the competitive position of a brand in the marketplace. Empirical research in branding suggests various ways to as sess brand success/failure mainly falling under the umbrella of brand equity. In the one hand, market-based objective measures (e.g. Simon \& Sullivan, 1993) that are derived from sales evaluate how many customers buy the brand, how often, and how much they also buy other brands (Ehrenberg, Uncles, \& Goodhardt, 2004). On the other hand, customer related measures (e.g. Keller, 1993) consider that it is the consumers that give value to brand and therefore their views must be included. This study echoes the second view and further argues that only consumers' perceptions are able to capture to what extent a given brand is different from its competitors through its perceived leadership.

Building on this theoretical perspective, two testable groups of hypotheses are developed around the argument that a proactive market oriented behaviour plays a significant role in strengthening company's position in the market place through higher customer's perceived leadership that may in return translate into enhanced perceived value of its branded products and ultimately generate superior performance expressed through its reputation. The conceptual model developed for this study in Figure I is presented below. It specifies the relationships among four constructs that are proactive market orientation, perceived branded product leadership, perceived customer value, and corporate reputation. 
Figure 1. Conceptual model and hypothesized relationships

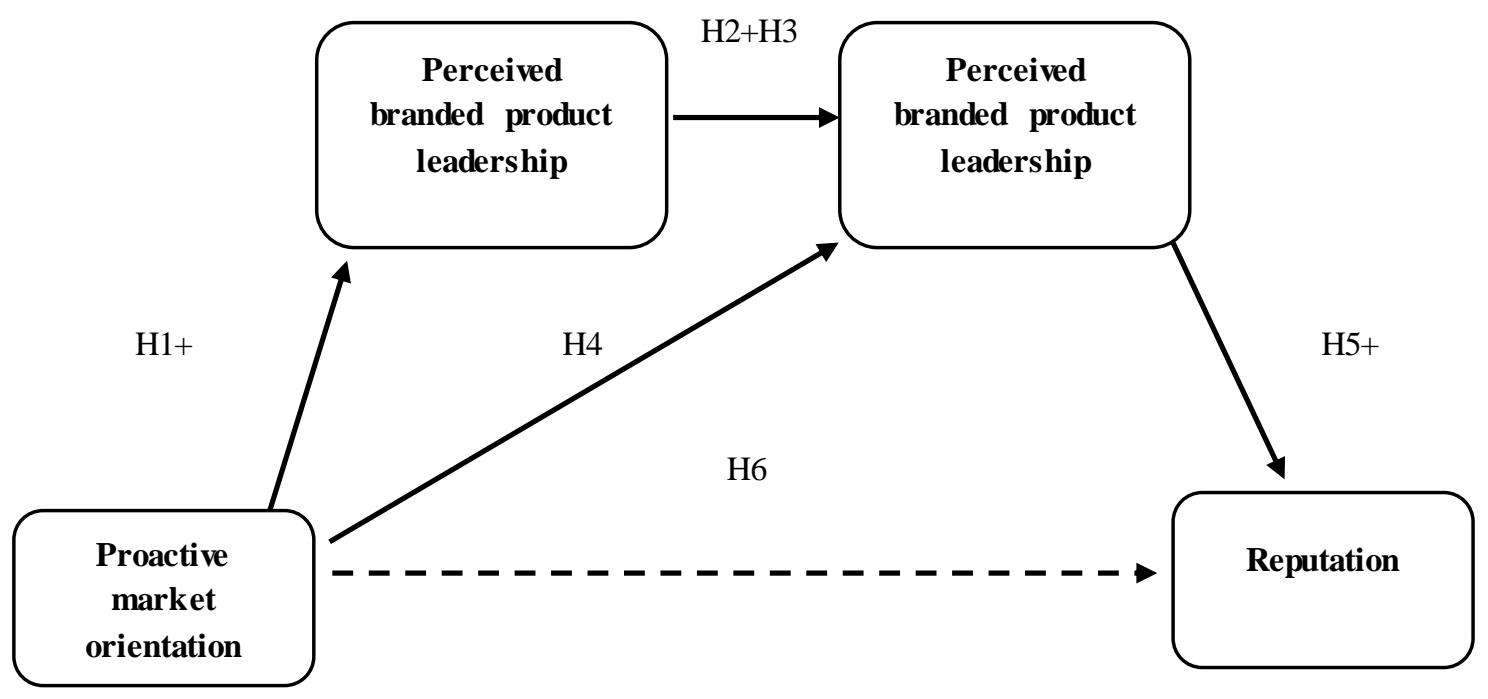

\section{The Proactive Market Orientation-Perceived Customer Value Relationship}

Prior research on market orientation has identified (perceived) customer value as its theoretical fundamental objective (e.g. Shapiro, 1988) and recent studies attempted to provide insights for mediating factors as exposed earlier in this paper. However, to the best or our knowledge, there is no reported empirical investigation in the context of consumer goods companies providing evidence that the link is direct. In this regard, we suggest that potential mediators that reflect a firm's ability to develop differentiated branded products that translate into superior value for the customer (and finally higher performance) are worth to be considered. Here, differentiation means developing a unique position on an attribute that is "widely valued by buyers" (Porter, 1985, p. 14). Indication of uniqueness can be found in the consumer-based brand equity literature through the notion of brand (name) awareness. The latter plays a crucial role in consumer decision making in helping consumers to correctly discriminate one brand seen or heard previously over its competitors and making it easier to as sociate to a specific product category (Keller, 1993). Here, (branded product) leadership refers to "consumers' perception about the relatively distinctive ability of a brand to continually achieve excellence through sufficient combinations of trendsetting and brand positioning within an industry segment" (Chang \& Ko, 2014, p. 65). This individual buyer's evaluation is also relevant to tap market dynamics such as sales leadership and customer acceptance (Aaker, 2012). In line with this reasoning, we argue that branded product leadership signals the uniqueness that is held in one company and not another in the extent to which a given one "clearly dominates" the others, and would differentiate those that have adopted a proactive market oriented behaviour from others that have not. In other words, company's proactive market oriented behaviour should be reflected in how the branded product's position is perceived in the marketplace. Taking this view and extending previous research, we expect a positive link between proactive market orientation and perceived leadership of branded products. Thus:

H1. A firm's proactive market orientation has a significant positive effect on cus tomer's perceived leadership of its branded products.

From the customer's point of view, the literature on the effect of the brand on the perceptions, preferences, and attitude of a customer (e.g. Bendixen, Bukasa, \& Abratt, 2004; Holbrook, 1992; Keller, 1993; Krishnan, 1996; ), distinguishes the performance of the brand from that of the product, to is olate the contribution of the brand to the utility given by a customer to a branded product. In this approach, the brand is considered an extrinsic element whose characteristics are not fully captured in the value judgments (DeSarbo, Jedidi, \& Sinha, 2001). Then, the brand is supposed to have an influence on the evaluation of the attributes of the branded product through a halo effect and a direct influence on the preference for the branded product (see Urban \& Hauser, 1980). On the one hand, this is consistent with the results 
of Dodds, Monroe, and Grewal (1991) who found that a favourable brand name has a positive influence on buyers' value perceptions. On the other hand, Cretu and Brodie (2007) found no influence of branding attributes (i.e. brand image) on customer perceived value in a business-to-consumer setting. In an effort to extend previous research, we hypothesise the following:

H2. Customer's perceived leadership of a firm's branded products has a significant positive effect on customer's perceived value of firm's branded products.

To the best or our knowledge, the mediating role of customer's perceived leadership of a firm's branded products in the relationship between proactive market orientation and customer's perceived value is not well-documented. Consequently, this paperadds to the literature by presuming that in consumer goods markets, a market oriented culture that proactively find new ways to differentiate a company's branded products is needed to deliver superior perceived value for its customers. Hence,

H3. Customer's perceived leadership of a firm's branded products mediates the relationship between firm's proactive market orientation and customer's perceived value of its branded products.

\section{The Proactive Market Orientation-Performance Relationship}

While Kohli and Jaworski (1990) and Narver and Slater (1990) found a positive effect of market orientation on performance, Blocker, Flint, Myers, and Slater (2011) reported no direct link between proactive customer orientation and performance evaluated subjectively. Indeed, its influence derives from perceived customer value, though Blocker et al. did not examine the potential mediating role of the latter. Overall, these authors stressed that empirical investigation in the market orientation literature is significantly underdeveloped when it comes to subjective evaluations of its consequences, i.e. in terms of performance metrics.

Because product markets can quickly appear and fade (D'Aveni, 1995), non-financial benchmarks have gained increased importance in a way that prompts companies to keep an eye on both customers and best practices in all dimensions of their business (Kaplan \& Norton, 1992). Gupta, Lehmann, and Stuart (2004) demonstrated the value of customer-focused metrics for shareholder value. In addition, Petersen, McAlister, Reibstein, Winer, Kumar, and Atkinson (2009) emphasized the need for not only the right metrics but also the proper implementation as a mean to produce better results. In other words, recognizing the role of the customer in driving firm's success is not sufficient if companies do not use customer-related measures that mirrors such a claim at the operational level (Shamma \& Hassan, 2013). Research on brand equity has identified several variables, based on customers and an aggregation of several firm characteristics such as reputation (see Sharp, 1996).

The dominant research paradigm describes reputation in terms of informational content brought about through its different dimensions (e.g. the emotional appeal of a company, its products and services, vision and leadership; see Fombrun, Gardberg, \& Sever, 2000). In order to delineate corporate reputation from concepts such as corporate image and corporate identity, Berens, van Riel, and van Bruggen (2005) proposed they reflect different kinds of 'corporate associations'. In line with this reasoning and following the works of other scholars (e.g. Brown, Dacin, Pratt, \& Whetten, 2006; Walsh, Mitchell, Jackson, \& Beatty, 2009), in terms of conceptualization we consider that reputation refers to mental associations about a firm actually detained by others outside the firm, the latter being one specific stakeholder group that are customers and the associations they hold about the (proactively market oriented) company they purchased branded products. As such, branded product and corporate as sociations are bounded.

Regarding its role, reputation alternatively plays the role of an antecedent because it influences the decisions of investors and competitors in situations of incomplete information (Weigelt \& Camerer, 1988). It also derives from organizational factors, such as corporate culture (e.g. Camerer \& Vepsalainen, 1988), social indicators (e.g. Bermiss, Zajac, \& King, 2014); and customer related variables such as product quality (e.g. Gatti, Caruana, \& Snehota, 2012). Under these conditions, reputation plays the role of a perceptual resource in the minds of various stakeholders on performance (de Chernatony, Harris, \& Christodoulides, 2004). In the causal chain we defined, reputation is a consequence of the interaction between a company's (proactive) market orientated behaviour and how the latter 
translates into customer perceived leadership and perceived customer value of its branded products. Here, it is argued that the link between proactive market orientation and reputation is not direct. It is worth noting that to the best of our knowledge, there is in no reported empirical investigation that confirms or invalidates this assumption. Otherwise, in the absence of reported empirical evidence on the relationship between perceived customer value and reputation, thus, we propose the following:

H4. Customer's perceived value of a firm's branded products mediates the relationship between a firm's proactive market orientation and its reputation as perceived by its customers.

H5. Customer's perceived value of a firm's branded products has a significant positive effect on a firm's reputation as perceived by its customers.

H6. A firm's proactive market orientation has no direct influence on its reputation as perceived by its customers.

\section{RESEARCH METHOD}

\section{Measurement of Constructs}

Manager-Related Construct

Proactive market orientation (PMO) was measured using Narver, Slater, and MacLachlan's (2004) seven-item scale. The managers indicated the extent to which they agreed or disagreed with statements about their firms' current busines practices $(1=$ strongly dis agree, $6=$ strongly agree $)$.

\section{Customer-Related Constructs}

Leadership position of a firm's branded products is assessed through customers' perceptions instead of a (dichotomous) market-based distinction on whether the company is first or second in a specific product category. Building on the work of Aaker (1995) and MacInnis and Nakamoto (1991), we used three items to tap into its absolute and relative components. We did not retain the item on innovation in the measurement instrument developed by Aaker (1995) because of the possibility that the item would influence respondents' answers to the other measurement items; rather, we preferred a more general approach to perceived branded product leadership (for a discussion, see Na, Son, \& Marshall, 2007). The customers indicated the extent to which the brand is "one of the worst" (1) to "one of the best" (6) (MacInnis \& Nakamoto 1991), and is the best in class and is becoming more renowned (Aaker, 1995) on a 6 point Likert scale. We measured perceived customer value using two items adapted from the ACSI model (Fornell, Johnson, Anders on, Cha, \& Bryant, 1996). While this choice may be disputable, it aims to ease operationalization of the value concept in interpreting it in terms of the ratio of benefits to sacrifices (e.g., Zahorik \& Rust, 1992; Zeithaml, 1988). The instructions and items asked the customers to rate the quality relative to the price of the branded product $(1=$ very poor price given the quality, $6=$ very good price given the quality) and to rate the price relative to the quality of the branded product $(1=$ very poor quality given the price, $6=$ very good quality given the price $)$. This measurement is close to the value-for-money as sessment developed by Aaker (1996). We measured reputation using the 20 items of the Reputational Quotient (RQ) developed by Fombrun, Gardberg, and Sever (2000). The customers indicated the extent to which they agreed or disagreed with statements about the reputation of the company from which they bought the branded products on the six dimensions of the RQ (e.g. emotional appeal, products and services, financial performance, vision and leadership, working environment, and social and environmental responsibility; $1=$ strongly disagree, $6=$ strongly agree).

\section{Sampling and Data Collection}

The study is based on a survey of both consumer goods companies and their customers in France. As part of a multisource perspective, we thus collected data from both managers/executives and customers on different concepts using a double questionnaire protocol. 
Firstly, a sample of consumer goods companies was selected from multiple business sources, including lists of companies traded on stock markets in and outside the Euro-zone (EURONEXT databases). Specifically, the nonrandom sample consisted of 63 consumer goods companies from a cross section of industries such as computers, cosmetics, automotive, and clothing, with full national coverage. The key criteria for company selection was that it is selling branded products and it generates a turnover greater than $€ 100$ million. We sought to obtain at least 2 companies competing against each otherper industry.

Secondly, we developed a questionnaire dedicated to the executives of the selected consumer goods companies and related to proactive market orientation in line with the procedure Narver, Slater, and MacLachlan (2004) recommend. In parallel, we developed a questionnaire dedicated to the customers of those companies based on the operationalization of perceived branded product leadership, perceived customer value, and reputation variables. All items and modalities were subjected to double translation. Both questionnaires were pretested twice (Churchill, 1979) before being administered to each specific sample. This procedure helped better clarify the purpose of the survey and rephrase sentence formulations, especially in the case of perceived customer value measurement items.

In this study, company managers belonging to the middle management level (executives) were used as the key informants, because they work in close collaboration with the advertising/sales functions, customer service, and R\&D, as well as more strategic or transversal functions (Narver \& Slater, 1990). The contact data came from the alumni directories of several business schools belonging to the Paris Chamber of Commerce as well as our own business network. We paid careful attention to revising questions and response options in a way that was meaningful to respondents (Conant, Mokwa, \& Varadarajan, 1990). To improve the response rate from man agers, who are hampered by time constraints (see Wu, Balasubramanian, \& Mahajan, 2004), a brief introductory text explained the purpose of the survey and its interest in improving business practices and also highlighted the confidentiality of the responses (Dillman, 1978). The manager questionnaire was administered by telephone (after an e-mail contact), e-mail, or fax, depending on the contact person's preferred method.

With regard to the manager sample of companies, we selected buyers of the branded products to whom these companies were selling, i.e. branded product has the same brand name as the company they originate from. We undertook the American Customer Satisfaction Index (ACSI) methodology (see ACSI Methodology Report, 2001) to qualify a consumer as a buyer if he or she had purchased branded products within a given period. In this regard, we defined purchasing cycles by product type and in relation to the industries. Moreover, in order to link the brand and product levels of analysis associated with customer variables in the theoretical model, we assumed that brand associations influenced consumer product responses (see Brown \& Dacin, 1997) and vice versa. The customer questionnaire was administered face-to-face and by e-mail. For both manager and customer questionnaires, $T$-tests showed no statistically significant difference between data collection methods (significance level of .01).

In total, 162 usable manager questionnaires from 63 companies were returned. The response rate is virtually hundred percent because rather than sending out a questionnaire to a mailing list, our selected business contacts showed from the beginning their interest in participating in the research project. We dropped single companies in a specific industry from the dataset, which resulted in a usable sample size of 146 respondents from 55 firms. Regarding the number of returns per company, this result is rather consistent with previous works on the market orientation performance relationship (e.g. Narver, Slater, \& MacLachlan, 2004). The sample consisted of companies operating in consumer goods industries such as L'Oréal (Paris), Apple, Renault, Nestlé, Dell, Nintendo, and New Balance.

The job titles of respondents showed that marketing functions are largely dominant: 70 percent were product or brand managers and 12 percent were marketing directors. The 18 percent remaining, most were managers working in sales, $\mathrm{R} \& \mathrm{D} / \mathrm{prospective,} \mathrm{and} \mathrm{customer} \mathrm{service/relationships} \mathrm{departments.}$

In addition, we collected 425 usable customer surveys. The customer convenience sample consisted of $48.2 \%$ men and 51.8\% women living in the city of Paris intra-and extra muros, covered a wide range of educational levels, and is not over-represented by students: those holding a master degree accounted for 62 percent, followed by bachelor holders (21 percent), college graduates (10 percent), and MBA and doctorate graduates (7 percent). It is worth noting that the relatively highly educated characteristic of our sample may result from a "capital effect", the region [Ile-deFrance to which Paris belongs to] attracting many firms that hire highly skilled people (Blanchard \& Ferrer, 2007). 


\section{ANALYSIS AND RESULTS}

\section{Measure Purification}

Manager and customer data were analysed using principal component analysis (see Field, 2013). Factor loading of 0.40 was used as cut-off criterion in deciding which item to remove (see Nunally, 1978). Results revealed that all items loaded appropriately on their respective constructs except for reputation: one item - "this company offers products and services that are good value for money" - did not meet the loading criterion (0.39) and was subsequently deleted. Overall, proactive market orientation, perceived branded product leadership, and perceived customer value had similar structure to that identified in previous studies except reputation. For all scales, alpha coefficients indicate acceptable reliability as values exceed the threshold of 0.7 (Nunnally \& Bernstein, 1994) for proactive market orientation (0.75), perceived branded product leadership (0.84), perceived customer value (0.80), and reputation (0.95). Descriptive statistics and preliminary analyses' results are presented in Table I.

Table 1. Descriptive statistics and preliminary analy ses

\begin{tabular}{|c|c|c|c|c|}
\hline Variables & Mean & $\begin{array}{l}\text { Standard } \\
\text { deviation }\end{array}$ & Loadings & $\begin{array}{c}\text { Composite } \\
\text { reliability }(\rho)\end{array}$ \\
\hline Proactive market orientation & & & & 0.88 \\
\hline $\begin{array}{l}\text { We continuously try to discover additional needs of } \\
\text { our customers of which they are unaware }\end{array}$ & 4.65 & 1.252 & 0.71 & \\
\hline $\begin{array}{l}\text { We incorporate solutions to unarticulated customer } \\
\text { needs in our new products and services }\end{array}$ & 4.27 & 1.309 & 0.74 & \\
\hline $\begin{array}{l}\text { We brainstorm on how customers use our products } \\
\text { and services }\end{array}$ & 4.38 & 1.351 & 0.53 & \\
\hline $\begin{array}{l}\text { We innovate even at the risk of making our own } \\
\text { products obsolete }\end{array}$ & 4.26 & 1.526 & 0.91 & \\
\hline $\begin{array}{l}\text { We search for opportunities in the areas where } \\
\text { customers have a difficult time expressing their needs }\end{array}$ & 4.18 & 1.18 & 0.58 & \\
\hline $\begin{array}{l}\text { We work closely with lead users who try to recognize } \\
\text { customer needs months or even years before the } \\
\text { majority of the market may recognize them }\end{array}$ & 3.73 & 1.654 & 0.83 & \\
\hline $\begin{array}{l}\text { We extrapolate key trends to gain insight into what } \\
\text { users in a current market will need in the future }\end{array}$ & 4.6 & 1.279 & 0.72 & \\
\hline Perceived branded product leadership & & & & 0.80 \\
\hline This brand is one of the best & 4.16 & 1.24 & 0.75 & \\
\hline This brand is the best in class & 3.64 & 1.35 & 0.82 & \\
\hline This brand is becoming more renowned & 3.77 & 1.448 & 0.69 & \\
\hline Perceived customer value & & & & 0.82 \\
\hline Rating of price given quality & 3.89 & 1.131 & 0.86 & \\
\hline Rating of quality given price & 4.12 & 1.079 & 0.80 & \\
\hline Reputation & & & & 0.94 \\
\hline \multicolumn{5}{|l|}{ Emotional Appeal } \\
\hline I have a good feeling about this company & 4.03 & 1.194 & 0.74 & \\
\hline I admire and respect this company & 3.68 & 1.288 & 0.72 & \\
\hline I have confidence in this company & 3.99 & 1.216 & 0.77 & \\
\hline \multicolumn{5}{|l|}{ Products and Services } \\
\hline $\begin{array}{l}\text { This company stands behind its products and } \\
\text { services }\end{array}$ & 4.27 & 1.235 & 0.55 & \\
\hline $\begin{array}{l}\text { This company offers high-quality products and } \\
\text { services }\end{array}$ & 4.22 & 1.207 & 0.73 & \\
\hline $\begin{array}{l}\text { This company develops innovative products and } \\
\text { services }\end{array}$ & 3.90 & 1.306 & 0.54 & \\
\hline $\begin{array}{l}\text { This company offers products and services that are } \\
\text { good value for money }\end{array}$ & 3.97 & 1.065 & 0.39 & \\
\hline
\end{tabular}

(Table 1 continued on next page) 
(Table 1 continued)

\begin{tabular}{|c|c|c|c|c|}
\hline Reputation & & & & 0.94 \\
\hline \multicolumn{5}{|l|}{ Vision and Leadership } \\
\hline This company has excellent leadership & 3.68 & 1.054 & 0.65 & \\
\hline This company has a clear vision for its future & 3.71 & 1.132 & 0.64 & \\
\hline $\begin{array}{l}\text { This company recognizes and takes advantage of } \\
\text { market opportunities }\end{array}$ & 3.95 & 1.237 & 0.66 & \\
\hline \multicolumn{5}{|l|}{ Workplace Environment } \\
\hline This company is well managed & 3.84 & 1.132 & 0.71 & \\
\hline $\begin{array}{l}\text { This company looks like a good company to work } \\
\text { for }\end{array}$ & 3.72 & 1.033 & 0.51 & \\
\hline $\begin{array}{l}\text { This company looks like a company that would have } \\
\text { good employees }\end{array}$ & 3.83 & 1.025 & 0.56 & \\
\hline \multicolumn{5}{|l|}{ Social Responsibility } \\
\hline This company supports good causes. & 2.92 & 1.223 & 0.82 & \\
\hline $\begin{array}{l}\text { This company is an environmentally responsible } \\
\text { company. }\end{array}$ & 3.01 & 1.113 & 0.83 & \\
\hline $\begin{array}{l}\text { This company maintains high standards in the way it } \\
\text { treats people. }\end{array}$ & 3.21 & 1.123 & 0.75 & \\
\hline \multicolumn{5}{|l|}{ Financial Performance } \\
\hline This company has a strong record of profitability & 3.82 & 1.217 & 0.68 & \\
\hline This company looks like a low-risk investment & 3.59 & 1.237 & 0.61 & \\
\hline This company tends to outperform its competitors & 3.64 & 1.319 & 0.68 & \\
\hline $\begin{array}{l}\text { This company looks like a company with strong } \\
\text { prospects for future growth }\end{array}$ & 3.95 & 1.199 & 0.69 & \\
\hline
\end{tabular}

The preliminary analyses' results indicated that the psychometric properties of the measurement instruments were good. In order to verify robustness of the data, we as ses sed both convergent and discriminant validity.

We first evaluated internal consistency, also called composite reliability, on the basis of "actual construct loadings" (White, Varadarajan, \& Dacin, p. 71). As Table 1 shows, the composite reliabilities for the PMO, perceived branded product leadership, perceived customer value, and reputation scales ranged from 0.8 to 0.94. Although Skervalaj, Stemberger, Skrinjar, and Dimovski (2007) argued that there is no general acceptable benchmark for acceptable composite reliability, Kim and Malhotra (2005) noted that a score greater than 0.7 is sufficient.

Secondly, convergent validity was assessed by examining the Average Variance Extracted (AVE) of the four constructs. AVE was calculated on the basis of the squared multiple correlations from the confirmatory factor analysis (CFA). Convergent validity is established because the AVE for each of the PMO (0.53), perceived branded product leadership (0.57) and perceived customer value (0.69) constructs exceeds the level of 0.5 recommended by Fornell and Larcker (1981) and Bagozzi, Yi, and Phillips (1991). For the reputation (0.46) construct, despite values being below the 0.5 threshold, these results are also acceptable according to Diamantopoulos and Siguaw (2000). Moreover, all the standardised factor loadings were statistically significant at the $1 \%$ level, also in support of convergent validity (Gerbing \& Anderson, 1988).

Finally, we assessed discriminant validity only for perceived branded product leadership, perceived customer value, and reputation because the managers' perceptions of PMO were not rated using the same questionnaire as customer related variables (see Netemeyer \& Maxham, 2007). Table II shows that discriminant validity is supported because for any two constructs, their respective reliabilities are larger than their squared correlation estimates (Fornell \& Larcker 1981; Hair, Black, Babin, Anderson, \& Tatham, 2006). Hence, perceived branded product leadership, perceived customer value, and reputation are distinct constructs. 
Table 2. Construct-level internal consistency and correlations

\begin{tabular}{l|c|c|c}
\hline \multicolumn{1}{c|}{ Constructs** } & $\begin{array}{c}\text { Perceived branded } \\
\text { product leadership }\end{array}$ & $\begin{array}{c}\text { Perceived } \\
\text { customer value }\end{array}$ & Reputation \\
\hline Perceived branded product leadership & $\mathbf{0 . 8 4}$ & 0.145 & 0.219 \\
\hline Perceived customer value & $0.382^{*}$ & $\mathbf{0 . 8 2}$ & 0.199 \\
\hline Reputation & $0.469^{*}$ & $0.447 *$ & $\mathbf{0 . 9 4}$ \\
\hline
\end{tabular}

* Correlation is significant at the .01 level.

** Note: correlations are below the diagonal, squared correlations are above the diagonal, reliabilities are presented on the diagonal.

\section{Hypotheses Testing}

Although from a methodological point of view it is difficult to connect customer perception measures with organizational variables (Parasuraman, Berry, \& Zeithaml, 1991), we accounted for these difficulties in collecting data so that they would not hinder our research efforts (see Zeithaml, 2000). In this study, data collection was based on one firm/manager-level variable (i.e. PMO) and the three customer-related variables of perceived branded product leadership, perceived customer value, and reputation, resulting in two distinct groups of questionnaires. All measurement instruments were verified in terms of their appropriateness and robustness for further analyses.

Therefore, prior to hypotheses testing and as a consequence of the multisource approach we adopted, we compiled a list of branded products evaluated by customers and a list of related companies and their managers. Then, we aggregated scores for each of the four constructs by computing the arithmetic mean of both (individual) managers' [proactive market orientation] and customers' [perceived branded product leadership, perceived customer value, and reputation] responses (see Kumar, Stern, \& Anderson, 1993). Finally, we merged managers' (146) and customers' (425) scores on the same branded products in a single dataset (55) that contained one response per company on each assessed variable. Consistently with previous research (Tabachnick \& Fidell, 2001), the final sample used for examining hypotheses contains "at leastfive cases for each observed variable" (p. 603).

To test the hypotheses which focus on investigating the mediating role of perceived branded product leadership and perceived customer value in the relationship between proactive market orientation and performance (i.e. reputation), the method suggested by Preacher and Hayes (2008a) was considered particularly suitable in the case of a three-path model (two mediators in series). We did not use structural equation modelling (SEM) because in this case mediation refers to a causal path between the variables, which has been criticized because of some limits in the testing of more than one potential mediator simultaneously (MacKinnon, 2000). In addition, SEM may not offer a statistical test of indirect effects (see MacKinnon, Lockwood, Hoffman, West, \& Sheets, 2002). Figure II depicts the overall path diagram: the total mediated effect of X (PMO) on Y (reputation) was broken down into a three-path mediated effects model, which indicates the effect passing through both mediators (M1 and M2), and a two-path mediated effects model, which indicates the effects passing through only one mediator (M1). We also considered one additional mediated effect, that is, the one passing through of another mediator (M2).

Table 3. Mediation of the effect of PMO on reputation through perceived branded product leadership and perceived customer value.

\begin{tabular}{l|c|c|cc}
\hline \multirow{2}{*}{ Paths } & \multirow{2}{*}{ Point estimate } & \multirow{2}{*}{$\begin{array}{c}\text { Product of } \\
\text { coefficients } \boldsymbol{S E}\end{array}$} & \multicolumn{2}{c}{$\begin{array}{c}\text { Bootstrapping } \\
\text { Percentile 95\% CI }\end{array}$} \\
\cline { 3 - 5 } & & & Lower & Upper \\
\hline PMO -> BPLEAD -> REP & 0.125 & 0.048 & 0.040 & 0.229 \\
\hline PMO -> BPLEAD -> PCV -> REP & 0.027 & 0.017 & 0.005 & 0.073 \\
\hline PMO -> PCV -> REP & 0.007 & 0.015 & -0.017 & 0.047 \\
\hline TOTAL & .159 & .06 & .048 & .277 \\
\hline
\end{tabular}

Note : 1000 bootstrap samples; Significance $=.000(p<.0005)$. BPLEAD $=$ perceived branded product leadership, REP $=$ reput ation, and PCV $=$ perceived customer value.

Accordingly, for each of the three defined effects, we estimated regression equations: in the first equation, $\beta 1$ is the regression of M1 (perceived branded product leadership) on X (PMO); in the second equation, $\beta 2$ is the regression of M2 (perceived customer value) on M1 (perceived branded product leadership), and $\beta 5$ is the regression of M2 (perceived customer value) on X (PMO); in the third equation, $\beta 6$ is the regression of Y (reputation) on M1 (perceived 
branded product leadership), $\beta 3$ is the regression of $\mathrm{Y}$ on $\mathrm{M} 2$, and $\beta 4$ is the regression of $\mathrm{Y}$ on $\mathrm{X}$. We expected the paths from $X$ to $M 1(\beta 1)$, from M1 to M2 $(\beta 2)$, and from M2 to $Y(\beta 3)$ to be positive.

To estimate the extent and significance of the indirect effects, we implemented a bootstrapping strategy (here, the percentile bootstrap), as several authors (e.g. Bollen \& Stine, 1990; MacKinnon, Lockwood, \& Williams, 2004; Shrout $\&$ Bolger, 2002) advocate in the case of multiple mediation models (see Preacher and Hayes, 2008b; Taylor, MacKinnon, \& Tein, 2008). We used the SPSS PROCESS macro (see Hayes, 2012) to estimate the coefficients $\beta 1$, $\beta 2$, and $\beta 3$ for the multiple mediation model to test the total and specific indirect effects. In our case - that is, a multiple mediator model - the bootstrapping strategy does not impose the assumption of normality of the sampling dis tribution (Preacher \& Hayes, 2008b).

The model including PMO, perceived branded product leadership, and perceived customer value explained $72.5 \%$ (adjusted $\mathrm{R}^{2}=.725 ; p<.0005$ ) of the variance in reputation. Insofar as we were interested in indirect effects, we examined the difference between the total and direct effects (i.e. the total indirect effect) through the two mediators. We first examined the total effect of the independent variable on the dependent variab le to validate a mediated effect (see Kenny, Kashy, \& Bolger, 1998), though this step is not always necessary to establish mediation (see Taylor, MacKinnon, \& Tein, 2008). The results established that there is an effect of $X$ on $Y$ to be mediated $(\beta=.208 ; \mathrm{t}=2.89$; $\mathrm{p}=.0056)$. We then tested the direct effect of $\mathrm{X}$ on $\mathrm{Y}$, controlling for both mediators. $\beta 4$ is 0.05 and is not significant $(p>.272)$, suggesting that PMO has no direct effect on reputation, in support of H6. Finally, with a point estimate of 0.159 and a $95 \%$ boots trap confidence interval (CI) of $0.048-0.277$, we can claim that the difference between the total and the direct effect of PMO on reputation is different from zero.

Then, we examined specific indirect effects. As Table III shows, among the coefficients making up the mediated effects, both $\beta 1$ (.125) and $\beta 2$ (.027) were significantly nonzero. For the $\beta 1$ (LL =.040 and UL $=.229)$ and $\beta 2$ (LL $=$ .005 and $\mathrm{UL}=.073)$ paths, since their $95 \%$ Confidence Interval $(\mathrm{Ci})$ did not contain zero, i.e. the null hypothesis of no mediation was rejected, it indicates that perceived branded product leadership and perceived customer value mediated the relationship between PMO and reputation. Thus, $\mathrm{H} 2$ and $\mathrm{H} 4$ are validated. With these results, we found support for the model, such that the effect of PMO on reputation was mediated by two variables acting in turnperceived branded product leadership and perceived customer value. Finally, the directions of the $\beta 1$ and $\beta 2$ paths are consistent with the interpretation that higher levels of PMO lead to greater perceived branded product leadership ( $\beta 1$ $=.286 ; \mathrm{t}=5.28 ; \mathrm{p}=.01)$, which in turn leads to greater perceived customer value $(\beta 2=.41 ; \mathrm{t}=5.26 ; \mathrm{p}=.0000)$ and, thus, higher reputation $(\beta 3=.23 ; \mathrm{t}=2.43 ; \mathrm{p}=.01)$. These results provided support for $\mathrm{H} 1, \mathrm{H} 3$, and $\mathrm{H} 5$.

Figure 2. Path diagram of the three-path mediated effects model

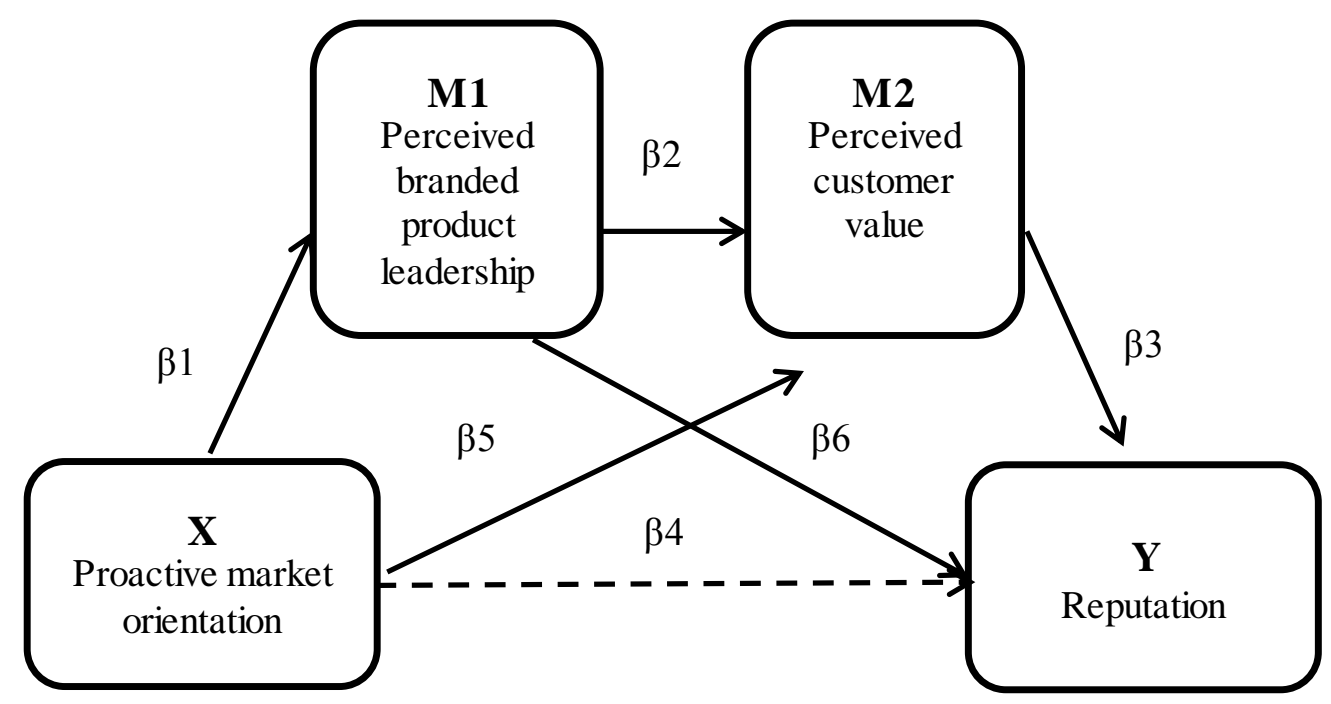




\section{DISCUSSION}

Anecdotal evidence (see Srinivasan, Rangaswamy, \& Lilien, 2005; see also, O’Malley, Story, \& O’Sullivan, 2011) suggests that leading firms develop a proactive approach to the markets they serve in order to reveal disguised opportunities through customers' latent needs and finally reach success. Previous literature exploring the proactive market oriented behaviour of companies and its consequences in terms of perceived customer value and performance outcomes is scarce in a consumer packaged goods setting.

At a theoretical level, the results of our study show that companies that practice a high level of proactive market orientation are able to develop and commercialize leading branded products as perceived by their customers, which leads to a higher price-quality trade-off (i.e. perceived customer value) than what competition has to offer. In turn, perceived customer value increases company performance as measured subjectively by its reputation. Moreover, we identify two mediating paths - proactive market orientation $\rightarrow$ perceived branded product leadership $\rightarrow$ perceived customer value and proactive market orientation $\rightarrow$ perceived customer value $\rightarrow$ reputation.

This study adds to the recent scholarly research on the proactive market orientation-performance relationship (e.g. Tan \& Liu, 2014; Kharabsheh, Jarrar, \& Simeonova, 2015) by empirically examining the role of two mediators in the case of consumer goods companies that received limited empirical attention. Results point out that company's ability to reveal unexpressed customer needs (through a proactive market oriented behaviour) contributes to differentiate and leverage its branded products, sustain its price-quality competitive position and finally its performance/reputation. As such, proactive market orientation fosters an innovation-based differentiation strategy that may contribute to maintain a leading position and escape competition (see Porter, 1980). Furthermore, while many scholars considered the success of a brand as an outcome (e.g. Chaudhuri \& Holbrook, 2001; Ngo \& O'Cass, 2011), this study reveals that the latter evaluated through its perceived leadership is a missing link not previously conceptualised in the context of how (proactive) market orientation contributes to enhance customer attitudinal assessments of its offering, i.e. branded products in the present study. Thus, our results contribute empirically to the literature that argues that asso ciations with the brand represent its ability to generate an additional customer utility than only the perceived value terms of a price-quality trade-off and therefore to transfer performance to its related products (Kamakura \& Russell, 1993; Park \& Srinivasan, 1994).

In the causalchain we defined, reputation is a consequence of the interaction between the actions of the company and customer attitude that directly or indirectly influences firm performance. We used it as a metric that differentiates between companies because a strong reputation offers the firm a valuable resource that it can continue to exploit to strengthen its position in the market (Snoj, Milfelner, \& Gabrijan, 2007). In examining the antecedents of reputation, we addressed the need for extending research on the relationship between organization culture [such as (proactive) market orientation that is here conceptualized as a busines s culture (see Narver \& Slater, 1990)] and reputation (e.g. Collins \& Porras, 1997; Flatt \& Kowalckzyk, 2000). We empirically assessed and identified perceived customervalue as a customer-related construct that mediates the relationship between proactive market orientation (an organizational antecedent) and reputation using a multisource perspective (the company and its customers).

Consequently, this research empirically adds to the literature on the organizational antecedents of reputation that indicates that when consumers evaluate a firm, they consider not only its performance but also how it communicates information about its corporate culture (Flatt \& Kowalczyk, 2000). We assumed that this information was communicated by the intermediary variables of perceived leadership and perceived value of the branded product, both of which directly or indirectly influence firm reputation. Overall, we decided to use reputation as a single construct instead of considering it as an item of an aggregated measure such as brand performance (e.g. Wong \& Merrilees, 2008) in order to capture a broader spectrum of associations because people often hold a variety of perceptions regarding a company (Berens \& van Riel, 2004). This decision may also constitute a limitation to the present study that we discuss below.

Our research design based on a manager-customer (i.e. multisource) perspective aimed at combining strategic and operational variables. In addition, the design included both independent and dependent measures from different origins. The goal of incorporating perceptions of customers and different organizational variables was to explain the 
variance in company performance. Indeed, the growing interactions between companies and customers suggest that company activities through the eyes of customers not only are critical measures of performance but also provide the basis for the firm's marketing philosophy (see Drucker, 1954). Thus, this dual perspective facilitates the emergence of value opportunities for firms to learn about the perceptions of their customers (Krepapa, Berthon, Webb, \& Pitt, 2003). Finally, we provided empirical support to the recent work of Terawatanavong, Whitwell, Widing, and O'Cass (2011) in suggesting that end customers are qualified to construe evaluations of a branded product offer, which reflects the market orientation level of the company.

\section{MANAGERIAL IMPLICATIONS}

Our findings have also implications for practitioners. Our results echo recent managerial issues such as "how to actively shape consumer decision journey" (see Edelman \& Singer, 2015). To do so, firms should be able to establish control over the decisions of their customers by suggesting decision criteria (that would reflect the outcome of their proactive market oriented behaviour) which customers will use to make choices among increasingly homogeneous brands and products. Dominant consumer goods companies may poss ess such characteristics, i.e. that their leadership in a given market can be used by consumers as a decision rule to buy their branded products instead of those of competitors. In this regard, we found that consumer goods companies that proactively manage their branded products in revealing unexpressed needs are able to differentiate them from competition and maintain their leadership in a product category despite increased commoditization. As such, they hold a unique position in the marketplace, and presumably in the minds of their customers. In other words, the creation of a leadership position starts with linking a firm behaviour and customer attitudes towards its branded products over the course of the creation of a competitive advantage.

Finally, in addition to monitoring sales and market share levels, our results advocate managers to consider corporate reputation as a valuable performance metric because its key constituents when compared to other rival companies signal how its customers think and feel about it, and thus may also represent a critical driver for differentiation.

\section{LIMITATIONS AND DIRECTIONS FOR FUTURE RESEARCH}

Our study has several limitations that open directions for further research. Here, we considered that proactive market orientation strengthens consumer goods companies' capacity to respond to an increasingly hostile environment by focusing on revealing consumers' unexpress ed needs. However, we did not consider how proactive market orientation is deployed. In this regard, scholars have stressed the importance of possessing specific [complementary] capabilities that represent "the glue that brings organizational assets together and deploys them advantageously" (Theodosiou, Kehagias, \& Katsikea, 2012, p. 1060). In line with Morgan, Vorhies, and Mason (2009) and Morgan (2012) who noted that cross-functional marketing capabilities such as the brand management capability may play a crucial role, we suggest that future research include the latter because they may be an important additional source of competitive advantage particularly for consumer goods companies operating on saturated markets. In addition, more attention should be paid to the role played by dynamic marketing capabilities such as market seizing that links firm's innovativeness to products and markets (Jantunen, Ellonen, \& Johansson, 2012).

Consistently with previous research (see Fornell, Johnson, Anderson, Cha, \& Bryant, 1996), we "ambitiously" expected our model to be applicable to multiple sectors and product categories. It is worth noting that multi-sector examination is far from being unusual not only in market orientation but also in consumer goods studies. For instance, Carroll and Ahuvia (2006) when studying the relationships between the type of product, satisfaction, brand love, and word-of-mouth, asked individual respondents to report on 170 unique brands in 66 different packaged goods categories. In a similar vein, Fetscherin, Boulanger, Filho, and Souki (2014) investigated the effect of product category on consumer brand relationships using a sample of 800 consumers accross four product categories. In line with this study, future research may consider the potential influence of the product category on the relationships between proactive market orientation and various brand related variables.

In terms of construct measurement, while we used a quality/price trade-off approach of perceived customer value (see Zeithaml, 1988), further research could use a more sophisticated instrument such as the one developed by Sweeney \& 
Soutar, (2001). This decision should be regarded in light with the one related to the consequences of perceived customer value and particularly reputation because both would be close in terms of their constituting dimensions and therefore may not be sufficiently distinct constructs.

In line with this reasoning, we chose the RQ (see Fombrun, Gardberg, \& Sever 2000) to capture the complexity of reputation. The feedback gathered during the pre-test of the customer questionnaire revealed that certain dimensions seemed less relevant in light of the group questioned (e.g. social responsibility). Thus, we recommend that future studies consider other approaches to ensure that reputation is examined from a specific stakeholder perspective (Puncheva-Michelotti \& Michelotti, 2010) because group and is sue-specific (Walker, 2010).

\section{AUTHOR BIOGRAPHY}

Laurent Tournois (PhD) is Research Associate at University of Nantes (LEMNA). His research interests are in the field of market oriented approaches, proactive cannibalization processes and proliferation strategies on both mature and developing economies. He published in the Journal of Applied Business Research, Journal of Retailing \& Consumer Services, and Journal of Business Strategy.

\section{REFERENCES}

Aaker, D.A. (1995). Building strong brands, New York: The Free Press.

(1996). Measuring brand equity across products and markets. California Management Review, 38(3), 102-120.

(2012). Building strong brands. New York: Simon and Schuster.

----- \& Joachimsthaler, E.A. (2000). The brand relationship spectrum: The key to the brand architecture challenge. California Management Review, 42(4), 8-23.

American Customer Satisfaction Index (2001). Methodology report. American Society for Quality, Claes Fornell International, Chicago: University of Michigan Business School.

Atwater, L.E., Brett, J.F., \& Charles, A.C. (2007). Multisource feedback: Lessons learned and implications for practice. Human Resource Management, 46(2), 285-307.

Bagozzi, R.P., Yi., Y., \& Phillips, L.W. (1991). Assessing construct validity in organizational research. Administrative Science Quarterly, 36(3), 421-458.

Ben Brik, A., Rettab, B., \& Mellahi, K. (2010). Market orientation, corporate social responsibility, and business performance. Journal of Business Ethics, 99(3), 307-324.

Bendixen, M., Bukasa, A., \& Abratt, R. (2004). Brand equity in the business-to-business market. Industrial Marketing Management, 33(5), 371-380.

Berens, G., \& van Riel, C.B.M. (2004). Corporate associations in the academic literature: Three main streams of thought in the reputation measurement literature. Corporate Reputation Review, 7(2), 161-178.

Berens, G., van Riel, C.B.M., \& van Bruggen, G.H. (2005). Corporate associations and consumer product responses: The moderating role of corporate brand dominance. Journal of Marketing, 69(3), 35-48.

Bermiss, Y.S., Zajac, E.J., \& King, B.G. (2014). Under construction: How commensuration and management fashion affect corporate reputation rankings. Organization Science, 25(2), 591-608.

Blanchard, N., \& Ferrer, A. (2007). Ile-de-France among the European regions. INSEE. Retrieved from http://www.insee.fr/fr/themes/document.asp?ref_id=11545.

Blocker, C.P., Flint, D.J., Myers, M.B., \& Slater, S.F. (2011). Proactive customer orientation and its role for creating perceived customer value in global markets. Journal of the Academy of Marketing Science, 39(2), 216-233.

Bodlaj, M. (2010). The impact of a responsive and proactive market orientation on innovation and business performance. Economic and Business Review for Central and South - Eastern Europe, 12(4), 241-261.

Bollen, K.A., \& Stine, R. (1990). Direct and indirect effects: Classical and bootstrap estimates of variability. Sociological Methodology, 20(1), 115-140.

Bourgeois, L.J. III (1984). Strategic management and determinism. Academy of Management Review, 9(4), 586-596.

Bracken, D.W., Timmreck, C.W., Fleenor, J.W., \& Summers, L. (2001), “360 Feedback from Another Angle”, Human Resource Management, 40 (1,) 3-20.

Brown, T.J., \& Dacin, P.A. (1997). The company and the product: Corporate associations and consumer product respons es. Journal of Marketing, 61(1), 68-84.

Brown, T.J., Dacin, P.A., Pratt, M.G., \& Whetten, D.A. (2006). Identity, intended image, construed image, and reputation: An interdisciplinary framework and suggested terminology. Journal of the Academy of Marketing Science, 34(2), 99-106.

Camarero, C., \& Garrido, M.J. (2008). The role of technological and organizational innovation in the relation between market orientation and performance in cultural organizations. European Journal of Innovation Management, 11(3), 413-434.

Copyright by author(s); CC-B Y 
Camerer, C., \& Vepsalainen, A. (1988). The economic efficiency of corporate culture. Strategic Management Journal, 9, 115126.

Carbonell, P., \& Rodriguez Escudero, A. (2010). The effect of market orientation on innovation speed and new product performance. Journal of Business \& Industrial Marketing, 25(7), 501-513.

Carroll, B.A., \& Ahuvia, A.C. (2006). Some antecedents and outcomes of brand love. Marketing Letters, 17(2), 79-89.

Chang, Y., \& Ko, Y.J. (2014). The brand leadership: Scale development and validation. Journal of Brand Management, 21(1), 63-80.

Chaudhuri, A., \& Holbrook, M.B. (2001). The chain of effects from brand trust and brand affect to brand performance: The role of brand loy alty. Journal of Marketing, 6(2), 81-93.

Chou, C., \& Yang, K.P. (2011). The interaction effect of strategic orientations on new product performance in the high-tech industry: a nonlinear model. Technological Forecasting and Social Change, 78(1), 63-74.

Churchill, G.A. (1979). A paradigm for developing better measures of marketing constructs. Journal of Marketing Research, $16(1), 64-73$.

Collins, J.C., \& Porras, J. (1998). Built to last: Successful habits of visionary companies. London: Random House.

Conant, J., Mokwa, M., \& Varadarajan, P. (1990). Strategic types, distinctive marketing competencies and organizational performance: a multiple measures-based study. Strategic Management Journal, 11(5), 365-383.

Cretu, A.E., \& Brodie, R.J. (2007). The influence of brand image and company reputation where manufacturers market to small firms: A customer value perspective. Industrial Marketing Management, 36(2), 230-240.

D'aveni, R.A. (1995). Coping with hy percompetition: Utilizing the new 7S's framework. Academy of Management Executive, 9(3), 45-57.

de Chernatony, L., Harris, F., \& Christodoulides, G. (2004). Developing a perceived brand leadership measure for financial services brands. The Service Industries Journal, 24(2), 15-33.

Deephouse, D.L., \& Carter, S.M. (2005). An examination of differences between organizational legitimacy and organizational reputation. Journal of Management Studies, 42(2), 329-360.

DeSarbo, W.S., Jedidi, K., \& Sinha, I. (2001). Perceived customer value analy sis in a heterogeneous market. Strategic Management Journal, 22(9), 845-857.

Deshpandé, R., Farley, J.U., \& Webster, F.E. (1993). Corporate culture, customer orientation and innovativeness in Japanese firms: A quadrad analy sis. Journal of Marketing, 57(1), 23-37.

Diamantopoulos, A., \& Siguaw, J.A. (2000). Introducing LISREL. London: Sage.

Dillman, D.A. (1978). Mail and telephone surveys: The total design method. New York: Wiley \& Sons.

Dodds, W.B., Monroe, K.B., \& Grewal, D. (1991). Effects of price, brand, and store information on buy ers' product evaluations . Journal of Marketing Research, 28(3), 307-319.

Drucker, P.F. (1954). The practice of management. New York: Harper and Row.

Edelman, D., \& Singer, M. (2015). Competing on customer journeys. Harvard Business Review, November. Retrieved from https://hbr.org/2015/11/competing-on-customer-journeys.

Ehrenberg, A.S.C., Uncles, M.D., \& Goodhardt, G.J. (2004). Understanding brand performance measures: Using Dirichlet benchmarks. Journal of Business Research, 57(12), 1307-1325.

Ellinger, A.E., Ketchen, D.J., Hult, G.T.M., Elmadag, A.B., \& Richey, R.G. (2008). Market Orientation, employ ee development practices, and performance in logistics service provider firms. Industrial Marketing Management, 37(4), 353-366.

Fetscherin, M., Boulanger, M., Gonçalves Filho, C., \& Quiroga Souki, G. (2014). The effect of product category on consumer brand relationships. Journal of Product \& Brand Management, 23(2), 78-89.

Field, A.P. (2013). Discovering statistics using IBM SPSS statistics: and sex and drugs and Rock 'n' Roll. 4th ed., Thousand Oaks: Sage.

Flatt, S.J., \& Kowalczyk, S.J. (2000). Do corporate reputations partly reflect external perceptions of organizational culture?. Corporate Reputation Review, 3(4), 351-358.

Fombrun, C.J., Gardberg, N., \& Sever, J.M. (2000). The Reputation Quotient: A multi-stakeholder measure of corporate reputation. Journal of Brand Management, 7(4), 241-255.

Fornell, C., \& Larcker, D.F. (1981). Evaluating structural equations models with unobservable variables and measurement error. Journal of Marketing Research, 18(1), 39-50.

------, Johnson, M.D., Anderson, E.W., Cha, J., \& Bry ant, B.E. (1996). The American Customer Satisfaction Index: Nature, purpose, and findings. Journal of Marketing, 60(4), 7-18.

Gatti, L., Caruana, A., \& Snehota, I. (2012). The role of corporate social responsibility, perceived quality and corporate reputation on purchase intention: Implications for brand management. Journal of Brand Management, 20(1), 65-76.

Gerbing, D.W., \& Anderson, J.C. (1988). An updated paradigm for scale development incorporating unidimensionality and its assessment. Journal of Marketing Research, 25(2), 186-192.

Gehlhar, M.J., Regmi, A., Stefanou, S.E., \& Zoumas, B.L. (2009). Brand leadership and product innovation as firm strategies in global food markets. Journal of Product \& Brand Management, 18(2), 115-126.

Grisaffe, D.B., \& Kumar, A. (1998). Antecedents and consequences of perceived customer value: Testing an expanded framework. MSI Working Paper Series, 98-107, Cambridge: Marketing Science Institute, 1-42. 
Gupta, S., Lehmann, D.R., \& Stuart, J.A. (2004). Valuing customers. Journal of Marketing Research, 41(1), 7-18.

Hair, Jr., J.F., Black, W.C., Babin, B.J., Anderson, R.E., \& Tatham, R.L. (2006). Multivariate data analy sis. 6th ed., Upper Saddle River: Pearson-Prentice Hall.

Hay es, A.F. (2012). PROCESS: A versatile computational tool for observed variable mediation, moderation, and conditional process modelling. Retrieved from http://www.afhay es.com/ublic/process2012.pdf.

Heugens, P.P.M.A.R., Riel, C.B.M., \& van den Bosch, F.A.J. (2004). Reputation management capabilities as decision rules. Journal of Management Studies, 41(8), 1349-1377.

Holbrook, M. (1992). Product quality, attributes and brand name as determinants of price: The case of consumer electronics. Marketing Letters, 3(1), 71-83.

Hult, G.T.M., Ketchen D.J., \& Slater S.F. (2005). Market orientation and performance: An integration of disparate approaches. Strategic Management Journal, 26(12), 1173-1181.

Jantunen, A., Ellonen, H-K., \& Johansson, A. (2012). Beyond appearances - Do dy namic capabilities of innovative firms actually differ?. European Management Journal, 30(2), 141-55.

Jaworski, B., Kohli, A.K., \& Sahay, A. (2000). Market-driven versus driving markets. Journal of the Academy of Marketing Science, 28(1), 45-54.

Joachimsthaler, E. (2001). Perceived brand leadership - The new imperative. Retrieved from http://www.metroas.no/pdf/fagartikler/Brandleadership.pdf.

Kamakura, W.A., \& Russell, G.J. (1993). Measuring brand value with scanner data. International Journal of Research in Marketing, 10(1), 9-22.

Kaplan, R.S., \& Norton, D.P. (1992). The balanced scorecard - Measures that drive performance. Harvard Business Review, 70(1), 71-79.

Keller, K.L. (1993). Conceptualizing, measuring, and managing customer-based brand equity. Journal of Marketing, 57(1), 1-22.

Kenny, D.A., Kashy, D.A., \& Bolger, N. (1998). Data analy sis in social psychology, in Handbook of social psychology, 4th ed., Gilbert, D., Fiske, S. and Lindzey, G., eds., New-York: McGraw-Hill, 233-265.

Kharabsheh, R.A., Jarrar, K., \& Simeonova, B. (2015). The impact of competitive strategies on responsive market orientation, proactive market orientation, learning orientation and organizational performance. Journal of Strategic Marketing, 23(5), 423-435.

Kim, S.S., \& Malhotra, N.K. (2005). Predicting system usage from intention and past use: Scale issues in the predictors. Decision Sciences, 36(1), 187-196.

Kirca, A.H., Jayachandran S., \& Bearden W. (2005). A meta-analytic review and assessment of its antecedents and impact on performance. Journal of Marketing, 69(1), 24-41.

Kohli, A.K., \& Jaworski, B.J. (1990). Market Orientation: The Construct, Research Propositions, And Managerial Implications. Journal of Marketing, 54(2), 1-18.

Krepapa, A., Berthon, P., Webb, D., \& Pitt, L. (2003). Mind the gap: An analy sis of service provider versus customer perceptions of market orientation and the impact on satisfaction. European Journal of Marketing, 37(1/2), 197-218.

Krishnan, H.S. (1996). Characteristics of memory associations: A consumer-based brand equity perspective. International Journal of Research in Marketing, 13(4), 389-405.

Kumar, V., Jones, E., Venkatesan, R., \& Leone, R.P. (2011). Is market orientation a source of sustainable competitive advantage or simply the cost of competing? Journal of Marketing, 75(1), 16-30.

Lange, D., Lee, P.M., \& Dai, Y. (2011). Organizational reputation: A review. Journal of Management, 37(1), 153-184.

Langerak, F. (2001). The relationship between customer and supplier perceptions of the manufacturer's market orientation and its business performance. International Journal of Market Research, 43(1), 43-62.

MacInnis, D., \& Nakamoto, K. (1991). Factors that influence consumers' evaluations of brand extensions. unpublished working paper, Tucson: University of Arizona.

MacKinnon, D.P. (2000). Contrasts in multiple mediator models. in Multivariate applications in substance use research: New methods for new questions, Jennifer S. Rose, Laurie Chassin, Clark C. Presson, and Steven J. Sherman, eds., Mahwah: Lawrence Erlbaum Associates, 141-160.

-----, Lockwood, C.M., Hoffman, J.M., West, S.G., \& Sheets, V. (2002). A comparison of methods to test mediation and other intervening variable effects. Psychological Methods, 7(1), 83-104.

-----, -----, \& Williams, J. (2004). Confidence limits for the indirect effect: Distribution of the product and resampling methods. Multivariate Behavioural Research, 39(1), 99-128.

Morgan, N.A. (2012). Marketing and business performance. Journal of the Academy of Marketing Science, 40(1), $102-119$.

Morgan, N.A., Vorhies, D.W., \& Mason, C.H. (2009). Market orientation, marketing capabilities, and firm performance. Strategic Management Journal, 30(8), 909-920.

Na, W., Son, Y. \& Marshall, R. (2007). Why buy second best? The behavioural dy namics of market leadership. Journal of Product and Brand Management, 16(1), 16-22.

Narver, J.C., \& Slater, S.F. (1990). The effect of a market orientation on business profitability. Journal of Marketing, 54(4), 2035 .

------, ------, \& MacLachlan, D.L. (2004). Responsive and proactive market orientation and new-product success. The Journal of 
Product Innovation Management, 21(5), 334-347.

Netemeyer, R.G., \& Maxham, J. G. (2007). Employee versus supervisor ratings of performance in the retail customer service sector: Differences in predictive validity for customer outcomes. Journal of Retailing, 83(1), 131-146.

Ngo, L.V., \& O'Cass, A. (2011). The relationship between business orientations and brand performance: A cross-national perspective. Asia Pacific Journal of Marketing and Logistics, 23(5), 684-713.

Noble, C.H., Sinha, R.K., \& Kumar, A. (2002). Market orientation and alternative strategic orientations: A longitudinal assessment of performance implications. Journal of Marketing, 66(4), 25-39.

Nunnally, J.C. (1978). Psychometric theory. 2nd ed., New York: McGraw-Hill.

-----, \& Bernstein, I.H. (1994). Psy chometric theory. 3rd ed., New York: McGraw-Hill.

O'Cass, A., \& Viet Ngo, L. (2007). Market orientation versus innovative culture: Two routes to superior brand performance. European Journal of Marketing, 41(7/8), 868-887.

O’Malley, L., Story, V., \& O'Sullivan, V. (2011). Marketing in a Recession: Retrench or invest? Journal of Strategic Marketing, 19(3), 285-310.

Park, C.S., \& Srinivasan, V. (1994). A survey-based method for measuring and understanding brand equity and its extendibility. Journal of Marketing Research, 31(2), 271-288.

Parasuraman, A., Berry, L.L., \& Zeithaml, V.A. (1991). Refinement and reassessment of the SER VQUAL scale. Journal of Retailing, 67(4), 420-450.

Petersen, A.J., McAlister, L., Reibstein, D.J., Winer R.S., Kumar, V., \& Atkinson, G. (2009). Choosing the right metrics to maximize profitability and shareholder value. Journal of Retailing, 85(1), 95-111.

Porter, M.E. (1980). Competitive strategy. New York: The Free Press.

----- (1985). Competitive advantage: Creating and sustaining superior performance. New York: The Free Press.

Preacher, K.J., \& Hayes, A.F. (2008a). Asymptotic and resampling strategies for assessing and comparing indirect effects in multiple mediator models. Behaviour Research Methods, 40(3), 879-891.

-----, \& ----- (2008b). Contemporary ap proaches to assessing mediation in communication research. in The Sage sourcebook of advanced data analy sis methods for communication research, Andrew F. Hayes, Michael D. Slater, and Leslie B. Sny der, eds., Thousand Oaks: Sage, 13-54.

Puncheva-Michelotti, P., \& Michelloti, M.(2010). The role of the stakeholder perspective in measuring corporate rep utation. Marketing Intelligence and Planning, 28(3), 249-274.

Reimann, M., Schilke, O., \& Thomas, J.S. (2010). Toward an understanding of industry commoditization: Its nature and role in evolving marketing competition. International Journal of Research in Marketing, 27(2), 188-197.

Rong, R., \& Wilkinson, I.F. (2011). What do managers' survey responses mean and what affects them? The case of market orientation and firm performance. Australasian Marketing Journal, 19(3), 137-147.

Roshay ani, A., Siti Mariam, M., \& Rohana, O. (2012). Market orientation, firm performance and the mediating effect of corporate social responsibility. Journal of Applied Business Research, 28(5), 851-860.

Samli, A.C. (2006). Surviving in chaotic modern markets: Strategic considerations in turbulent times. Journal of Marketing Theory and Practice, 14(4), 315-322.

Shamma, H., \& Hassan, S. (2013). Customer-driven benchmarking: A strategic approach toward a sustainable marketing performance. Benchmarking: An International Journal, 20(3), 377-395.

Shapiro, B.P. (1988). What the hell is market oriented?. Harvard Business Review, 66(6), 119-125.

Sharp, B. (1996). Brand equity and market-based assets of professional service firms. Journal of Professional Services Marketing, 13(1), 3-8.

Shrout, P.E., \& Bolger, N. (2002). Mediation in experimental and non-experimental studies: New procedures and recommendations. Psy chological Methods, 7(4), 422-445.

Siguaw, J.A., Simpson, P.M., \& Baker, T.L. (1998). Effects of supplier market orientation on distributor market orientation and the channel relationship: The distributor perspective. Journal of Marketing, 62(3), 99-111.

Simon, C.J., \& Sullivan, M.W.(1993). The measurement and determinants of brand equity: A financial approach. M arketing science, 12(1), 28-52.

Skerlavaj, M., Indihar Stemberger, M., Skrinjar, R., \& Dimovski, V. (2007). Organizational learning culture - The missing link between business process change and organizational performance. International Journal of Production Economics, 106(2), 346-367.

Smither, J.W., London, M., \& Reilly, R.R. (2005). Does performance improve following multi-source feedback? A theoretical model, meta-analy sis, and review of empirical findings. Personnel Psychology, 58(1), 33-66.

Snoj, B., Milfelner, B., \& Gabrijan, V. (2007). An examination of the relationships among market orientation, innovation resources, reputational resources, and company performance in the transitional economy of Slovenia. Canadian Journal of Administrative Sciences, 24(3), 151-164.

Srinivasan, R., Rangaswamy, A., \& Lilien, G. (2005). Turning adversity into advantage: Does proactive marketing during a recession pay off?. International Journal of Research in Marketing, 22(2), 109-125.

Srivastava, P., Yoo, J., Frankwick, G., \& Voss, K. (2013). Evaluating the relationship of firm strategic orientations and new product development program performance. Journal of Marketing Theory and Practice, 21(4), 429-440. 
Sweeney, J.C., \& Soutar, G.N. (2001). Consumer perceived value: The development of a multiple item scale", Journal of Retailing, 77(2), 203-220.

Tabachnick, B.G., \& Fidell, L.S. (2001). Using multivariate statistics, 4th ed., Needham Heights: Allyn and Bacon.

Tan, M., \& Liu, Z. (2014). Paths to success: an ambidexterity perspective on how responsive and proactive market orientations affect SMEs' business performance. Journal of Strategic Marketing, 22(5), 420-441.

Taylor, A.B., MacKinnon, D.P., \& Tein, J.Y. (2008). Tests of the three-path mediated effect. Organizational Research Methods, 11(2), 241-269.

Terawatanavong, C., Whitwell, G.J., Widing, R.E., \& O’Cass, A. (2011). Technological turbulence, supplier market orientation, and buyer satisfaction. Journal of Business Research, 64(8), 911-918.

Theodosiou, M., Kehagias, J., \& Katsikea, E. (2012). Strategic orientations, marketing capabilities and firm performance: an empirical investigation in the context of frontline managers in service organizations. Industrial Marketing Management, 41(7), 1058-1070.

Tornow, W.W. (1993). Perceptions or reality: Is multi-perspective measurement a means or an end? Human Resource Management, 32(2-3), 221-229.

Tuominen, P. (1999). Managing brand equity. The Finnish Journal of Business Economics, 48(1), 65-100.

Uncles, M.D. (2011). Researching market orientation and business performance. Australasian Marketing Journal, 19(3), $161-164$.

Urban, G., \& Hauser, J. (1980). Design and marketing of new products. Englewood Cliffs: Prentice Hall.

von Hippel, E. (1986). Lead users: A source of novel product concepts. Management Science, 32(7), 791-805.

Voola, R., \& O'Cass, A. (2010). Implementing competitive strategies: The role of responsive and proactive market orientations . European Journal of Marketing, 44(1/2), 245-266.

-----, Casimir, G., Carlson, J., \& Agnihotri, M.A. (2012). The effects of market orientation, technological opportunism, and ebusiness adoption on performance: a moderated mediation analy sis. Australasian Marketing Journal, 20(2), 136-146.

Walker, K.A. (2010). A sy stematic review of the corporate reputation literature: Definition, measurement, and theory. Corporate Reputation Review, 12(4), 357-387.

Walsh, G., \& Beatty, S. E. (2007). Customer-based corporate reputation of a service firm: Scale development and validation. Journal of the Academy of Marketing Science, 35(1), 127-143.

------, Mitchell, V-W., Jackson, P.R., \& Beatty, S.E. (2009). Examining the antecedents and consequences of corporate reputation: A customer perspective. British Journal of Management, 20(2), 187-203.

Weigelt, K., \& Camerer, C. (1988). Reputation and corporate strategy: A review of recent theory and applications. Strategic Management Journal, 9(5), 443-454.

Whetten, D.A., \& Mackey, A. (2002). A social actor conception of organizational identity and its implications for the study of organizational reputation. Business \& Society, 41(4), 393-414.

White, J.C., Varadarajan, P.R., \& Dacin, P.A. (2003). Market situation interpretation and response: The role of cognitive sty le, organizational culture, and information use. Journal of Marketing, 67(3), 63-79.

Wong, H., \& Merrilees, B. (2008). The performance benefits of being brand oriented. Journal of Product and Brand Management, 17(6), 372-383.

Wu, Y., Balasubramanian, S., \& Mahajan, V. (2004). When is a preannounced new product likely to be delay ed?. Journal of Marketing, 68(2), 101-113.

Zahorik, A.J., \& Rust, R.T. (1992). Modelling the impact of service quality on profitability: A review. in Advances in Service Marketing and Management, T. Swartz, ed., Greenwich: JAI Press, 247-276.

Zeghal D., \& Maaloul A. (2010). Analysing value added as an indicator of intellectual capital and its consequences on company performance. Journal of Intellectual Capital, 11(1), 39-60.

Zeithaml, V.A. (1988). Consumer perceptions of price, quality, and value: A means-end model and synthesis of evidence. Journal of Marketing, 52(3), 2-22.

(2000). Service quality, profitability, and the economic worth of customers: What we know and What we need to learn. Journal of the Academy of Marketing Science, 28(1), 67-85.

Zhou, K.Z., Brown, J.R., \& Dev, C.S. (2009). Market orientation, competitive advantage, and performance: A demand-based perspective. Journal of Business Research, 62(11), 1063-1070. 


\section{NOTES}

